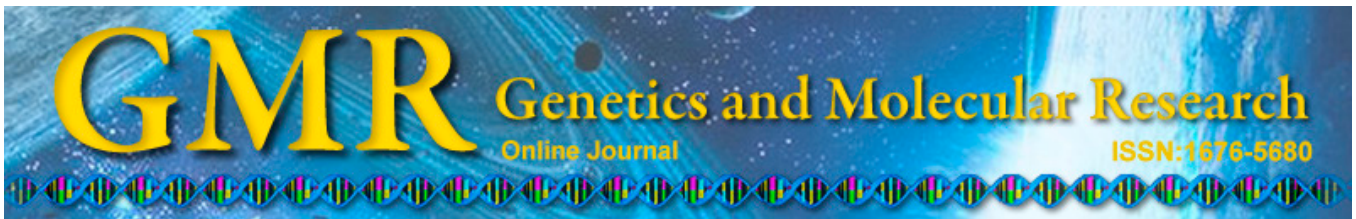

\title{
Assessment of the cytotoxic, genotoxic, and antigenotoxic activities of sucupira oil (Pterodon emarginatus)
}

\author{
L.A. Assunção ${ }^{1}$, S.R. Lemes ${ }^{2}$, L.A. Araújo ${ }^{1,3}$, C.R. Costa ${ }^{4}$, L.G. Magalhães ${ }^{4}$, \\ K.K. Moura ${ }^{1,2,5}$ and P.R. Melo-Reis ${ }^{1,2,5}$ \\ ${ }^{1}$ Laboratório de Estudos Experimentais e Biotecnologia, \\ Pontifícia Universidade Católica de Goiás, Goiânia, GO, Brasil \\ ${ }^{2}$ Pontifícia Universidade Católica de Goiás, Goiânia, GO, Brasil \\ ${ }^{3}$ Biotecnologia e Biodiversidade, Universidade Federal de Goiás, Goiânia, \\ GO, Brasil \\ ${ }^{4}$ Biomedicina, Pontifícia Universidade Católica de Goiás, Goiânia, GO, Brasil \\ ${ }^{5}$ Instituto de Farmácia e Ciências Biomédicas, \\ Pontifícia Universidade Católica de Goiás, Goiânia, GO, Brasil \\ Corresponding author: P.R. Melo-Reis \\ E-mail: melo.reis@ig.com.br
}

Genet. Mol. Res. 14 (2): 6323-6329 (2015)

Received August 25, 2014

Accepted December 2, 2014

Published June 11, 2015

DOI http://dx.doi.org/10.4238/2015.June.11.7

\begin{abstract}
The present study aimed to assess the cytotoxic, genotoxic, and antigenotoxic activities of sucupira oil (Pterodon emarginatus), which is commonly used as an anti-rheumatic, analgesic, antimicrobial, anticercariae, and anti-inflammatory. We used the mouse bone marrow micronucleus test as an experimental model. The experimental groups, which consisted of 5 animals, was administered sucupira oil $(100 \mathrm{mg} / \mathrm{kg}$ body weight) intraperitoneally and evaluated $24 \mathrm{~h}$ after the treatment. The negative control group was treated with sterile distilled water, and the positive control group received an intraperitoneal dose of $4 \mathrm{mg} / \mathrm{kg}$ mitomycin $\mathrm{C}$, a dose that corresponds to $80 \%$ of its median lethal dose. Cytotoxicity was determined by the polychromatic to normochromatic
\end{abstract}


erythrocytes ratio (PCE/NCE). Sucupira oil had no significant effects ( $\mathrm{P}$ $>0.05$ ) on the frequency of micronucleated polychromatic erythrocytes as compared to the negative control group. However, the difference was significant $(\mathrm{P}<0.005)$ as compared to the positive control group. The PCE/NCE (100 mg/kg oil and $4 \mathrm{mg} / \mathrm{kg}$ mitomycin) ratio did not differ between the experimental group and the positive control group, but it differed significantly when compared to the negative control group $(\mathrm{P}<$ $0.05)$. Thus, these findings suggested that the P. emarginatus oil showed no cytotoxic, mutagenic, or antimutagenic activities at a dose of 100 $\mathrm{mg} / \mathrm{kg}$.

Key words: Pterodon emarginatus; Micronuclei; Mice; Erythrocytes

\section{INTRODUCTION}

The use of medicinal plants and their extracts is a practice that dates back to centuries in human history (Ortencio, 1997). According to the World Health Organization (WHO, 2004 ), about $80 \%$ of the world population uses drugs that have therapeutic properties and are based on natural products (Mitscher et al., 1987; Chen et al., 2003).

However, several medicinal plants are not as innocuous as they seem to be. During the evolutionary process, some plants developed natural defense mechanisms such as the synthesis of toxic and genotoxic chemicals against bacteria, fungi, insects, and animal attacks (Castro et al., 2004; Melo-Reis et al., 2011). Many of these compounds were identified as mutagenic and carcinogenic and include flavonoids, hydrazines, furocoumarins, quinones, pyrrolizidine alkaloids, and theobromines (Ames, 1983; Khan et al., 2005).

Some of the natural products that are used for human nutrition may be causative agents or potentiators of cancer, whereas some may act as anticarcinogenics (Borek,1991). Several mutagenic and carcinogenic compounds are related to the formation of reactive oxygen species (ROS). ROS play a key role in degenerative processes such as DNA damage, mutations that are or are not related to cancer, heart disease, and aging (Mohan and Meltz,1994; Anderson et al., 1995).

However, some plants produce substances with antimutagenic properties such as betacarotene (vitamin A), ascorbic acid (vitamin C), tocopherols (Vitamin E), polyphenols, sulfhydryl compounds, calcium, fibers, and many other compounds (Karakaya and Kavas, 1999; Chen et al., 2003; Hiramatsu et al., 2004).

In Brazil, because of the high biodiversity of plant species, there is an increasing demand for natural resources (Castro et al., 2004). In Brazil, among the various plants with therapeutic potential, Pterodon emarginatus Vogel (syn. Pterodon pubescens Benth) stands out. It is popularly known as sucupira, sucupira-branca, or faveira, and it belongs to the Fabaceae (Leguminosae) family and Faboideae subfamily. Sucupira is a native aromatic arboreal species distributed throughout the states of Goiás, Mato Grosso do Sul, Minas Gerais, and São Paulo in Brazil; it is grown in the Brazilian Cerrado. The seeds (fava beans) of the plant are extensively useful for medicinal purposes owing to their antirheumatic (Coelho et al., 2004), analgesic (Coelho et al., 2005), antimicrobial (Santos et al., 2010), anticercariae (Mors et al., 1967), and anti-inflammatory properties (Denny, 2002). It is also used in the treatment of pharyngitis, bronchitis, and tonsillitis in humans. 
Dutra et al. (2009) shown that the diterpenes found in the oil of P. pubescens Benth fruits are effective in treating schistosomiasis. Thus, the bioactivity that is attributed to the fruit of this species is due to the presence of terpene compounds. The diterpenefuran-6-alpha7-beta-hydroxy-vouacapan has anti-inflammatory effects on edema that is induced by carrageenan (Hansen et al., 2010).

Since sucupira oil is widely used and its pharmacological and biological activities have been described in the literature, the present study aimed to assess the cytotoxic, genotoxic, and antigenotoxic activities of sucupira oil.

\section{MATERIAL AND METHODS}

\section{P. emarginatus oil}

Sucupira oil is extracted from the seed of $P$. emarginatus. It is viscous and bitter. Sucupira oil was purchased from a commercial vendor in the central market of Goiânia, Goiás. It was manufactured by Amazon Leve ${ }^{\circledR}$ (lot No. 010/12; date of manufacture October 2012; expiration date after 2 years).

\section{Animals}

Twenty healthy male outbred mice of the species Mus musculus belonging to the Swiss Webster strain were used. The mice had an average \pm standard deviation (SD) body weight (b.w.) of $25.0 \pm 2.5 \mathrm{~g}$, and they were 50 to 70 days old on the day of the experiment. The animals were placed in standard individual polypropylene cages with solid floors that were covered with sterilized wood chips according to international standards. The animals were housed in an environment with an average $\pm \mathrm{SD}$ temperature of $24 \pm 2{ }^{\circ} \mathrm{C}$ and a relative humidity of $55 \pm 5 \%$. The light-dark cycle was $12 \mathrm{~h}: 12 \mathrm{~h}$, and water and food were available ad libitum.

\section{Drugs and reagents}

Mitomycin C (MMC; 5 mg; Bristol-Myers Squibb, New York, NY, USA; Lot No. 2.JO1299; Expiration date, May 12, 2014) was used to evaluate the antimutagenicity of the plant oil. Fetal bovine serum (Laborclin Products Laboratories, Paraná, Brazil) was used to set up a growth supplement for cell culture. For the negative control, $5 \mathrm{~mL}$ sterile distilled water was used.

\section{Experimental design}

In order to assess the mutagenicity of sucupira oil, doses of $100 \mathrm{mg} / \mathrm{kg} \mathrm{b}$.w. were administered by intraperitoneal (ip) injections to 5 animals each in every treatment group. The negative control group was treated with sterile distilled water, while the positive control group received an ip dose of $4 \mathrm{mg} / \mathrm{kg} \mathrm{MMC}$, a dose that corresponds to $80 \%$ of the median lethal dose of MMC. The mice were killed by cervical dislocation $24 \mathrm{~h}$ after administration of the oil.

In order to analyze antimutagenicity, four groups with five animals each were admin- 
istered ip $100 \mathrm{mg} / \mathrm{kg}$ b.w. sucupira oil and $4 \mathrm{mg} / \mathrm{kg}$ b.w. MMC. Cervical dislocations were performed $24 \mathrm{~h}$ after the treatment.

Following the cervical dislocation, the femurs were removed. The femoral epiphyses were cut, and the bone marrow was washed with $1 \mathrm{~mL}$ fetal bovine serum. After bone marrow homogenization, it was centrifuged at $300 \mathrm{~g}$ for 5 minutes. The supernatant was partially discarded. The cell pellet was homogenized, and a drop of cell suspension was transferred onto a microscope slide in order to perform a cell smear. After drying the slides, they were fixed in absolute methanol for $5 \mathrm{~min}$ and stained in Leishman stain solution for $15 \mathrm{~min}$ (Heddle, 1973). The slides were then washed under running water and dried at room temperature. The cell smears and cell counts were performed by using a double-blind procedure.

\section{Cytogenetic analysis}

The analyses of the slides were performed with an ordinary optical Nikon microscope in order to detect possible changes and/or chromosomal loss (micronuclei) in polychromatic erythrocytes (PCE) from the bone marrow of animals subjected to the different treatments. The cells were visualized with an oil immersion objective (100X) and eye-piece (10X). Two microscope slides for each animal were used, and 1000 PCEs were evaluated in each slide. In order to evaluate cytotoxicity, we counted up to 1000 normochromatic erythrocytes (NCE) and the PCE/NCE ratio was determined according to Schmid (1975).

\section{Statistical analysis}

In order to analyze mutagenicity, the frequencies of micronucleated polychromatic erythrocytes (MNPCE) in 1000 PCEs in each group were compared with those in the negative or positive control group by using analysis of variance, and each pair was compared with a Tukey test. P values less than 0.05 were considered to be statistically significant.

We evaluated cytotoxicity by analyzing the frequencies of PCEs and NCEs in each group treated with sucupira oil and compared them with the negative and positive control group with Chi-square tests. $\mathrm{P}$ values less than 0.05 were considered to be statistically significant.

\section{RESULTS}

The results of the cotreatment with sucupira oil and MMC are shown in Table 1. No genotoxic or cytotoxic activity was observed. Mice treated with $100 \mathrm{mg} / \mathrm{kg}$ sucupira oil did not exhibit a significant difference in MNPCEs as compared to the negative control $(\mathrm{P}>0.05)$, while a statistically significant difference in MNPCEs was found in the mice treated with 100 $\mathrm{mg} / \mathrm{kg}$ sucupira oil as compared to the positive control $(\mathrm{P}<0.05)$.

The PCE/NCE ratio in the mice treated with a dose of $100 \mathrm{mg} / \mathrm{kg}$ oil and $4 \mathrm{mg} / \mathrm{kg}$ MMC was not significantly different as compared to the ratio in the positive control group. However, there was a significant difference $(\mathrm{P}<0.05)$ as compared to the ratio in the negative control group, as shown in Table 2. 
Table 1. MNPCE frequency compared to the PCE/NCE ratio after 24 hours of treatment with Pterodon emarginatus oil and control groups.

\begin{tabular}{lcccrc}
\hline & $\begin{array}{c}\text { Number of } \\
\text { animals }\end{array}$ & \multicolumn{2}{l}{ Micronucleated polychromatic erythrocytes (MNPCE) } & $\begin{array}{c}\text { PCE/NCE } \\
\text { ratio }\end{array}$ \\
\cline { 3 - 5 } & & $\begin{array}{c}\text { Individual data } \\
\text { MN } / 1000 \mathrm{PCE}\end{array}$ & $\%$ & $\begin{array}{r}\text { Mean } \pm \mathrm{SD} \\
\text { MN/1000PCE }\end{array}$ & \\
\hline $100 \mathrm{mg} / \mathrm{kg}$ body weight of sucupira oil & 5 & $3-1-2-0-1$ & 0.14 & $1.4 \pm 1.1^{\mathrm{a}}$ & $0.89^{\mathrm{c}}$ \\
$\mathrm{H}_{2} \mathrm{O}$ (negative control)* & 5 & $4-2-2-1-3$ & 0.28 & $2.8 \pm 0.83^{\mathrm{a}}$ & $0.88^{\mathrm{c}}$ \\
MMC (positive control)** $^{*}$ & 5 & $15-12-18-13-15$ & 1.46 & $14.6 \pm 2.30^{\mathrm{b}}$ & $0.46^{\mathrm{d}}$ \\
\hline
\end{tabular}

${ }^{a} \mathrm{P}>0.05 ;{ }^{\mathrm{b}} \mathrm{P}<0.05 ;{ }^{\mathrm{c}} \mathrm{P}>0.05 ;{ }^{\mathrm{d}} \mathrm{P}<0.05$. All results (test and positive control) were compared with the negative control group. $\mathrm{P}$ values below $0.05(\mathrm{P}<0.05)$ were considered to be significant. *Negative Control: distilled water; **Positive Control: MMC ( $4 \mathrm{mg} / \mathrm{kg}$ body weight).

Table 2. MNPCE frequency compared to the PCE/NCE ratio after treatment with MMC and Pterodon emarginatus oil at the same time.

\begin{tabular}{|c|c|c|c|c|c|}
\hline & \multirow{2}{*}{$\begin{array}{l}\text { Number of } \\
\text { animals }\end{array}$} & \multicolumn{3}{|c|}{ Micronucleated polychromatic erythrocytes (MNPCE) } & \multirow{2}{*}{$\begin{array}{l}\mathrm{PCE} / \mathrm{NCE} \\
\text { ratio }\end{array}$} \\
\hline & & $\begin{array}{l}\text { Individual data } \\
\mathrm{MN} / 1000 \mathrm{PCE}\end{array}$ & $\%$ & $\begin{array}{l}\text { Mean } \pm \text { SD } \\
\text { MN/1000PCE }\end{array}$ & \\
\hline $\begin{array}{l}100 \mathrm{mg} / \mathrm{kg} \text { body weight of sucupira } \\
\text { Oil }+4 \mathrm{mg} / \mathrm{kg} \mathrm{MMC}\end{array}$ & 5 & $11-13-14-17-12$ & 1.34 & $13.4 \pm 2.30^{b}$ & $0.53^{\mathrm{d}}$ \\
\hline $\mathrm{H}_{2} \mathrm{O}$ (negative control)* & 5 & $4-2-2-1-3$ & 0.28 & $2.8 \pm 0.83^{\mathrm{a}}$ & $0.88^{\mathrm{c}}$ \\
\hline MMC (positive control)** & 5 & $15-12-18-13-15$ & 1.46 & $14.6 \pm 2.30^{\mathrm{b}}$ & $0.46^{\mathrm{d}}$ \\
\hline
\end{tabular}

${ }^{\mathrm{a} P}>0.05 ;{ }^{\mathrm{b}} \mathrm{P}<0.05 ;{ }^{\mathrm{c}} \mathrm{P}>0.05 ;{ }^{\mathrm{d}} \mathrm{P}<0.05$. All results (test and negative control) were compared with the positive control group. $\mathrm{P}$ values below $0.05(\mathrm{P}<0.05)$ were considered to be significant. *Negative Control: distilled water; **Positive Control: MMC (4 mg/kg body weight).

\section{DISCUSSION}

Evaluation of the genotoxic activity of sucupira oil by the micronucleus test in the bone marrow of mice did not show an increased frequency of MNPCEs for the dose tested, as compared to the negative control group. This result indicated that the substance did not cause DNA damage (clastogenic action) or have aneugenic effects on the PCEs in the bone marrows of mice. These data corroborated the findings of other studies that have shown that high doses of sucupira oil resulted in no macroscopic changes in the body tissues of both humans and animals (Sabino et al., 1999; Coelho et al., 2004; Cardoso et al., 2008). In a different study, the clastogenicity of sucupira oil was examined in vivo in the bone marrow cells of Wistar rats. The analysis of metaphase showed that the compound did not induce a significant increase in the frequency of chromosomal aberrations (Dias et al., 1995).

The micronucleus assay that was applied in the present study allowed us to assess the cytotoxic effects by using the PCE/NCE ratio. The results indicated the non-cytotoxic effects of sucupira oil. The cotreatment of sucupira oil and MMC did not result in any differences when we compared the PCE/NCE ratio to that in the positive control group $(\mathrm{P}>0.05)$. This result indicated that the cotreatment of $100 \mathrm{mg} / \mathrm{kg}$ sucupira oil did not reduce the cytotoxic effects of MMC. Sabino et al. (1999) have performed mutagenic and histopathological analyses and demonstrated the absence of any damage after the administration of acute doses of sucupira oil. However, studies regarding the effects of sucupira oil in several organisms have shown potential cytotoxic activities that are usually not mutagenic (Stammati et al., 1999; 
Bakkali et al., 2008; Dutra et al., 2012).

Dutra et al. (2012) have found that doses of 0.5 to $5.0 \mu \mathrm{g}$ of Sucupira oil exhibit high toxicity in the crustacean Artemia salina and that these doses are 250 times more toxic as compared to thymol, which is a known toxic substance with a lethal dose of $1.63 \mathrm{mg} / \mathrm{mL}$ in A. salina.

Bioassays in brine shrimp and $A$. salina have shown strong cytotoxic activity of the oil in these models, and this effect was less intense in normal cells as compared to those in cancerous cells, suggesting a partial role in the inhibition of apoptosis pathways. It is noteworthy that ethylene oxide is an important compound of sucupira oil and is mainly responsible for this effect with a cellular influx of $47.0 \mu \mathrm{g} / \mathrm{mL}$ (Dutra et al., 2012). A reference half maximal inhibitory concentration $<10 \mathrm{mg} / \mathrm{mL}$ is considered highly toxic according to published guidelines, and it is therefore possible to deduce that this active compound indeed has high toxicity (Santos Pimenta et al., 2003; Dutra et al., 2008; Gad, 2009).

The analysis of antimutagenicity in the present study showed that cotreatment with $100 \mathrm{mg} / \mathrm{kg}$ oil and $4 \mathrm{mg} / \mathrm{kg}$ MMC had similar results as compared to the positive control group. There were no antimutagenic effects for the studied dose. This finding was consistent with the results of Sabino et al. (1999).

However, our results differed from those of other studies that have shown a positive antimutagenesis effect of sucupira oil. The antiproliferative effects of sucupira oil have been evaluated both in cancers (rat glioma, colon carcinoma in mice, human breast cancer, human melanoma, among others) and in normal cell lines by using [3-(4.5-dimethylthiazol-2-yl)]2-5-diphenyl tetrazolium-bromide assays based on cell viability, which indicated that doses between 24.9 and $47 \mu \mathrm{g} / \mathrm{mL}$ sucupira oil show cytotoxicity that is possibly caused by its active principles such as the diterpenoids (Dutra et al., 2012).

However, other studies have not shown evidence of the toxic or carcinogenic effects of diterpenes in humans; diterpenes are one of the most important active compounds of sucupira oil (Arriaga et al., 2000). In the United States, for example, most terpenes are defined as nontoxic by the Toxic Substance Control Act, the International Agency for Research on Cancer, and the National Toxicology Program (Missick, 1993).

Based on the results of these studies, it is tempting to hypothesize that sucupira oil can modulate DNA damage in tumor cells without affecting normal cells. Researchers, however, have highlighted that further investigations are essential in order to achieve a better understanding of its effects on DNA damage such as examining its effects through p53, Bcl-2, Bax, cytochrome $\mathrm{C}$, etc. or protein damage such as thioredoxin and glutathione, in cancer cells (Brown and Wouters, 1999; Dutra et al., 2009, 2012).

\section{CONCLUSIONS}

According to the data presented in this study, we concluded that sucupira oil does not present cytotoxic, genotoxic, or antigenotoxic activities. However, other studies show contradictory results when an active principle of sucupira oil is analyzed alone. Therefore, further studies should be conducted to test both the oil and some of its active compounds.

\section{REFERENCES}

Ames BN (1983). Dietary carcinogens and anticarcinogens. Science 221: 1256-1264.

Anderson D, Basaran N, Blowers SD and Edwards AJ (1995). The effect of antioxidants on bleomycin treatment in in vitro 
and in vivo genotoxic assays. Mutat. Res. 329: 37-47.

Arriaga AM, de Castro MA, Silveira ER and Braz-Filho R (2000). Further diterpenoids isolated from Pterodon polygalaeflorus. J. Braz. Chem. Soc.11:187-190.

Bakkali F, Averbeck S, Averbeck D and Idaomar M (2008). Biological effects of essential oil a review. Food Chem. Toxicol. 46: 446-475.

Borek C (1991). Free radical processes in multistage carcinogenesis. Free Radic. Res. Commun. 12: 745-750.

Brown JM and Wouters BG (1999). Apoptosis, p53, and tumor cell sensitivity to anticancer agents. Cancer Res. 59: 1391-1399.

Cardoso CC, Pinto AC, Marques PR, Gayer CR, et al. (2008). Suppression of T and B cell responses by Pterodon pubescens seeds ethanolic extract. Pak. J. Biol. Sci.11: 2308-2313.

Castro DB, Santos DB, Ferreira HD, Santos SC, et al. (2004). Atividades mutagênica e citotóxica do extrato de Cochlospermum regium Mart. (algodãozinho-do-campo) em camundongos. Rev. Bras. Pl. Méd. 6: 15-19.

Chen W, Weng YM and Tseng CY (2003). Antioxidative and antimutagenicactivities of healthy herbal drinks from Chinese medical herbs. Am. J. Chin. Med. 31: 523-532.

Coelho LP, Reis PA, de Castro FL, Gayer CR, et al. (2005). Antinociceptive properties of ethanolic extract and fractions of Pterodon pubescens Benth. seeds. J. Ethnopharmacol. 98: 109-116.

Coelho MG, Sabino KC and Dalmau SR (2004). Immunomodulatory effects of sucupira (Pterodon pubescens) seed infusion on collagen-induced arthritis. Clin. Exp. Rheumatol. 22: 213-218.

Denny C (2002). Atividade antiinflamatoria do óleo de sucupira: Pterodon pubescens Benth. Leguminosae-Papilionoideae. Master's thesis. Universidade Estadual de Campinas, Faculdade de Odontologia de Piracicaba, Piracicaba.

Dias Fda L, Takahashi CS, Sakamoto-Hojo E, Vichnewski W, et al. (1995). Genotoxicity of the natural cercaricides "sucupira" oil and eremanthine in mammalian cells in vitro and in vivo. Environ. Mol. Mutagen. 26: 338-344.

Dutra RC, Trevizani R, Pittella F and Barbosa NR (2008). Antinociceptive activity of the essential oil and fractions of Pterodon emarginatus Vogel seeds. Lat. Am. J. Pharm. 27: 865-870.

Dutra RC, Braga FG, Coimbra ES, Silva AD, et al. (2009). Antimicrobial and leishmanicidal activities of seeds of Pterodon emarginatus. Rev. Bras. Farmacogn. 19: 429-435.

Dutra RC, Pittella F, Dittz D, Marcon R, et al. (2012). Chemical composition and cytotoxicity activity of the essential oil of Pterodon emarginatus. Rev. Bras. Farmacogn. 22: 971-978.

Gad SC (2009). Alternatives to in vivo studies in toxicology. In: General, Applied and Systems Toxicology (Ballantyne B, Marrs TC and Syversen TL, eds.), v.6, John Wiley \& Sons, Inc., New York.

Hansen D, HaraguchiM and Alonso A (2010). Pharmaceutical properties of 'sucupira' (Pterodon spp.). Braz. J. Pharm. Sci. 46: 607-616.

Heddle JA (1973). A rapid in vivo test for chromosomal damage. Mutat. Res. 18: 187-190.

Hiramatsu N, Xiufen W, Takechi R, Itoh Y, et al. (2004). Antimutagenicity of Japanese traditional herbs, gennoshoko, yomogi, senburi and iwa-tobacco. BioFactors. 22: 123-125.

Karakaya S and Kavas A (1999). Antimutagenic activities of some foods. J. Sci. Food Agric. 79: 237-242.

Khan TH, Prasad L, Sultana A and Sultana S (2005). Soy isoflavones inhibits the genotoxicity of benzo(a) pyrene in Swiss albino mice. Hum. Exp. Toxicol. 24: 149-155.

Melo-Reis PR, Bezerra LS, Vale MA, Canhête RF, et al. (2011). Assessment of the mutagenic and antimutagenic activity of Synadenium umbellatum Pax latex by micronucleus test in mice. Braz. J. Biol. 71: 169-174.

Missick P (1993). Health and safety impacts of citrus-based terpenes in printed circuit board cleaning. The Massachusetts Toxics Use Reduction Institute, University of Massachusetts Lowell, Technical Report no. 6.

Mitscher LA, Drake S, Gollapudi SR and Okwute SK (1987). A modern look at folkloric use of anti-infective agents. $J$. Nat. Prod. 50: 1025-1040.

Mohan N and Meltz ML (1994). Induction of nuclear factor kappa B after low-dose ionizing radiation involves a reactive oxygen intermediate signaling pathway. Radiat. Res. 140: 97-104.

Mors WB, dos Santos Filho MF, Monteiro HJ, Gilbert B, et al. (1967). Chemoprophylactic agent in schistosomiasis: 14,15 epoxy geranylgeraniol. Science 157: 950-951.

World Health Organization - WHO (2004). 134 ${ }^{\text {a }}$ Sessão do ComitêExecutivo. Tema 4.4.Washington, D.C., EUA. Available at [http://www.paho.org/Portuguese/GOV/CE/ce134-12-p.pdf.] Accessed October 18, 2013.

Ortencio B (1997). Medicina Popular do Centro-Oeste. 2nd edn. Thesaurus, Brasília.

Sabino KC, Gayer CR, Vaz LR, Santos LR, et al. (1999). In vitro and in vivo toxicological study of the Pterodon pubescens seed oil. Toxicol. Lett. 108: 27-35.

Santos AP, Zatta DT, Moraes WF, Bara MT, et al. (2010). Composição química, atividade antimicrobiana do óleo essencial e ocorrência de esteroides nas folhas de Pterodon emarginatus Vogel, Fabaceae. Rev. Bras. Farmacogn. 20: 891-896.

Santos Pimenta LP, Pinto GB, Takahashi JA, e Silva LG, et al. (2003). Biological screening of Annonaceous brazilian medicinal plants using Artemia salina (Brine Shrimp Test). Phytomedicine 10: 209-212.

Schmid W (1975). The micronucleus test. Mutat Res. 31: 9-15.

Stammati A, Bonsi P, Zucco F, Moezelaar R, et al. (1999). Toxicity of selected plant volatiles in microbial and mammalian short-term assays. Food Chem. Toxicol. 37: 813-823. 